[Agr. Biol. Chem., Vol. 32, No. 10, p. 1212 1219, 1968]

\title{
Studies on Vitamin $\mathbf{B}_{6}$ Metabolism in Microorganisms
}

\author{
Part VI. Microbial Phosphorylation of Vitamin $B_{6}$ through a New \\ Phosphotransferring Reaction (2) \\ Some Properties of the Transphosphorylation
}

\author{
By Koichi Ogata, Yoshiki Tani and Tatsurokuro Tochikura \\ Department of Agricultural Chemistry, Kyoto University, Kyoto \\ Received April 18, 1968
}

\begin{abstract}
A large number of bacteria were searched for the activity of the synthesis of pyridoxine $5^{\prime}$-phosphate by the transphosphorylation between pyridoxine and $p$-nitrophenyl phosphate. Several properties of the transphosphorylation by the partially purified enzyme prepared from one of the isolated bacteria, Escherichia freundii $\mathrm{K}-1$, were investigated accompanying with phosphatase activity. The behavior of the phosphotransferase and phosphatase activities in various reaction conditions were almost parallel. It was pointed out that the transphosphorylation might be catalyzed by the function of acid phosphatase. The phosphoryl donor specificity for the enzyme system was found to be broad.
\end{abstract}

In a preceding paper, ${ }^{11}$ the phosphorylated product of pyridoxine (pyridoxol) was isolated from the reaction mixture which contained $p$-NPP and pyridoxine as the phosphoryl donor and acceptor substrates, and the cells of Aspergillus favus. It was also demonstrated that the phosphotransferring activity was distributed in various kinds of microorganisms, especially in fungi belonging to genus such as Aspergillus. The enzyme system which catalyzed the phosphotransferring reaction seemed to be different from pyridoxal kinase which phosphorylated pyridoxal, pyridoxamine and pyridoxine at the same rate in the phosphoryl group transfer from ATP. ${ }^{21}$

It has been known that such enzymatic transphosphorylation, which occurs without

The following abbreviations are used; pyridoxine$\mathrm{P}$, pyridoxine $5^{\prime}$-phosphate; pyridoxal-P, pyridoxal $5^{\prime}$-phosphate; pyridoxamine-P, pyridoxamine $5^{\prime}$-phosphate; $p$-NPP, $p$-nitrophenylphosphate; $p$-NP, $p$-nitrophenol.

1) K. Ogata, T. Tochikura, Y. Tani and S. Yamamoto, Agr. Biol. Chem., 30, 829 (1966).

2) D. B. McCormick, M.F. Gregory and E. E. Snell, J. Biol. Chem., 236, 2076 (1961). the participation of adenine nuclotidic compounds, might be catalyzed by the enzyme functions of the two different types., ${ }^{3,4)}$ One type is that of acid and alkaline phosphatases which have been studied on their phosphotransferring functions from the first work of Axelrod." Another type is that of phosphotransferase, such as nucleoside phosphotransferase $^{6,7)}$, the separation of which from phosphatase has been reported. ${ }^{8,91}$

This paper describes firstly the isolation of the bacteria which have a higher activity of the transphosphorylation of pyridoxine ac-

3) M. R. Atkinson and R. K. Morton, "Comparative Biochemistry", Vol. II, Academic Press, New York, 1960, p. 1.

4) R. Nordlie and H. Lardy, "The Enzymes",

Vol. 6, Academic Press, New York, 1962, p. 3.

5) B. Axelrod, J. Biol. Chem., 172, I (1948).

6) G. Brawerman and E. Chargaff, J.Am. Chem. Soc., 75, 2020 (1953).

7) H. Katagiri, H. Yamada, K. Mitsugi and T. Tsunoda, Agr. Biol. Chem., 28, 577 (1964).

8) M. Tunis and E. Chargaff, Biochim. Biophys. Acta, 37, 267 (1960).

9) E. F. Brunngraber and E. Chargaff, J. Biol. Chem., 242, 4834 (1967). 
companying with that of the hydrolyzation of the phosphoryl donor substrate. With the partially purified enzyme preparation from one of isolated bacteria, Escherichia freundii $\mathrm{K}-1$, several properties of the reaction were subsequently characterized.

\section{EXPERIMENTAL}

\section{Materials}

Microorganisms. Seven hundred and thirty bacterial strains were isolated from natural materials by plate culture method after static incubation at $37^{\circ} \mathrm{C}$ for $24 \mathrm{hr}$. Other microorganisms were the strains preserved in the Laboratory of Applied Microbiology, Department of Agricultural Chemistry, Kyoto University. These strains were cultured aerobically as described in a preceding paper. ${ }^{11}$ The cells were harvested by centrifugation or filtration and washed twice with deionized water. The washed cells were used for the following preparation of the enzyme. For the screening of the enzyme activity of the isolated bacteria, the culture fluid and air-dried cells were used as the enzyme preparations.

Enzyme preparation. The following operations for the preparation of the phosphotransferring enzyme were performed at $0 \sim 5^{\circ} \mathrm{C}$.

1) Cell free extracts preparation: The washed bacterial cells were suspended in $0.01 \mathrm{M}$ potassium phosphate buffer, pH 7.0, and treated with a KaijoDenki $19 \mathrm{~Hz}$ ultrasonic oscillator for $10 \mathrm{~min}$. The intact cells and debris were removed by centrifugation at $12,000 \times \mathrm{g}$ for $30 \mathrm{~min}$. The resulting supernatant solution was dialyzed against the same buffer overnight and then used as the bacterial cell free extract. While, the washed fungal cells were suspended in $0.1 \mathrm{M}$ potassium phosphate buffer, $\mathrm{pH}$ 7.0 , and ground with sea sand for about $30 \mathrm{~min}$. After centrifugation, the supernatant solution was dialyzed against $0.01 \mathrm{M}$ potassium phosphate buffer, $\mathrm{pH} 7.0$, and then used as the fungal cell free extract.

2) Partially purified enzyme preparation: The cell free extract of Escherichia freundii $\mathrm{K}-1$ was used as the starting material for the preparation of the partially purified enzyme preparation (Step I). The cell free extract was heated at $60^{\circ} \mathrm{C}$ for $10 \mathrm{~min}$ in a water bath. After the removal of the precipitate formed, the supernatant solution was dialyzed against deionized water (Step II). To the heat treated enzyme preparation the solid ammonium sulfate was added
Table I. Partial Purification of the Enzyme

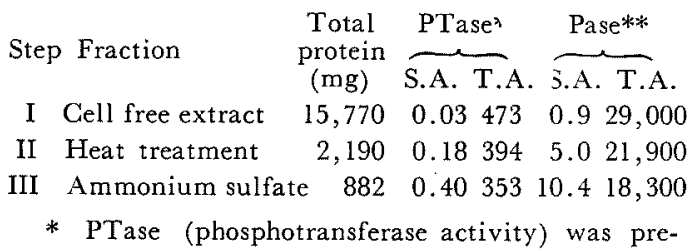
sented by the amount of pyridoxine-P formation in the standard enzyme assay conditions.

** Pase (phosphatase activity) was presented by the amount of $p-\mathrm{NP}$ formation in the standard enzyme assay conditions. S. A. (specific activity) was $\mu$ moles of $p$-NP or pyridoxine-P formed per $\mathrm{mg}$ of protein per $30 \mathrm{~min}$.

to $35 \%$ saturation with a gentle mixing. The precipitate formed was removed by centrifugation and discarded. An additional ammonium sulfate was added to the supernatant fluid, bringing the ammonium sulfate concentration to $65 \%$ saturation. The precipitate formed was dissolved in $0.01 \mathrm{M}$ potassium phosphate buffer, $\mathrm{pH} 7.0$, and then dialyzed against the same buffer overnight (Step III). The results of a preparation, in which the enzyme was purified about 10 fold with a recovery of $70 \%$ of the enzyme activity, are summarized in Table 1 .

Chemicals. $p$-NPP was kindly provided by $\mathrm{Dr}$. K. Mitsugi, Ajinomoto Co., Ltd. 5'-Nucleotides was the kind gifts of Takeda Pharm. Co., Ltd. Other chemicals were obtained from commercial sources.

Screening method. On the first screening for the isolation of the bacterial strains having a higher activity of the transphosphorylation, the following standard assay condition was used: The reaction mixture which contained $10 \mu$ moles of pyridoxine, $50 \mu$ moles of $p$-NPP, $200 \mu$ moles of potassium phos-

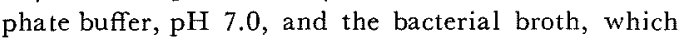
was cultured for $24 \mathrm{hr}$ and contained about $20 \mathrm{mg}$ of the cells as dry weight, was incubated in a total volume of $4 \mathrm{ml}$ at $28^{\circ} \mathrm{C}$ for $20 \mathrm{hr}$ on a reciprocal shaker. On the second screening, the following standard assay condition was used: The reaction mixture which contained $10 \mu$ moles of pyridoxine, $50 \mu$ moles of $p$-NPP, $200 \mu$ moles of potassium phosphate buffer, $\mathrm{pH} 6.6$, or sodium-potassium phosphate buffer, $\mathrm{pH} 11.0$, and approximately $20 \mathrm{mg}$ of the bacterial air-dried cells, was incubated in a total volume of $4 \mathrm{ml}$ for $20 \mathrm{hr}$ at $28^{\circ} \mathrm{C}$ on a reciprocal shaker. These reactions were stopped by heating the reaction mixture for $10 \mathrm{~min}$ in a boiling water bath. 
The reaction products were assayed after the removal of the cells with centrifugation at $5000 \times \mathrm{g}$ for 15 $\min$.

Identification of bacteria. Standard methods of identification were employed to determine the taxonoInic position of the isolated bacteria and referred to the "Bergey's Manual of Determinative Bacteriology", 7th Ed., 1957.101

Enzyme assay. The assay of the phosphorylation of pyridoxine accompanying with the hydrolyzation of phosphoryl donor substrate was conducted as follows. (1) For the assay with the cell free extract, the following standard condition was used: The reaction mixture which obtained $10 \mu$ moles of pyridoxine, $50 \mu$ moles of $p$-NPP, $250 \mu$ moles of potassium phosphate buffer, $\mathrm{pH} 6.6$, or glycine-NaCl-NaOH buffer, $\mathrm{pH} 10.0$, and $1 \mathrm{ml}$ of dialyzed cell free extract was incubated in a final volume of $3 \mathrm{ml}$ at $37^{\circ} \mathrm{C}$ for $2 \mathrm{hr}$. (2) For the assay with partially purified enzyme preparation from Escherichia freundii $\mathrm{K}-\mathrm{l}$, the following standard condition was used: The reaction mixture which contained $10 \mu$ moles of pyridoxine, $50 \mu$ moles of $p$-NPP, $200 \mu$ moles of Trismaleate buffer, $\mathrm{pH}$ 6.0, and appropriate amount of enzyme was incubated in a final volume of $3 \mathrm{ml}$ at $37^{\circ} \mathrm{C}$ for $30 \mathrm{~min}$. Pyridoxine-P and $\boldsymbol{p}$-NP measurements were made after stopping the enzyme reactions by heating for $10 \mathrm{~min}$ in a boiling water bath.

Analytical method. Pyridoxine-P, pyridoxal-P and pyridoxamine-P were determined as described in previous paper,") using mainly phenylhydrazine method.11) Para-nitrophenol was measured with the optical density at $430 \mathrm{~m} \mu$ with addition of saturated sodium carbonate solution. ${ }^{12}$ Protein was determined colorimetrically by the method of Lowry et al.13i using serum albumin as a reference standard.

\section{RESULTS}

The transphosphorylation activities of microorganisms.

In the first screening about thirty bacterial strains appeared to have the activity of the transphosphorylation between pyridoxine and $p$-NPP, and then several bacteria were selected by the second screening under the acidic and alkaline reaction conditions. The activities with cell free extract systems of the represent-

Table II. Phosphorylation of Pyridoxine

\begin{tabular}{|c|c|c|c|c|c|}
\hline \multirow{2}{*}{ Strain } & \multirow{2}{*}{$\begin{array}{l}\text { Protein } \\
\text { added } \\
(\mathrm{mg})\end{array}$} & \multicolumn{2}{|c|}{ Acidic site } & \multicolumn{2}{|c|}{ Alkaline site } \\
\hline & & PIN-P* & $p-\mathrm{NP}$ & PIN-P* & $p-\mathrm{NP}$ \\
\hline Isolated bacterium $\mathrm{K}-1$ & 8.5 & 0.42 & 21.8 & 0.03 & 4.5 \\
\hline 810 & 10.5 & 0.16 & 15.8 & 0.03 & 5.3 \\
\hline 68303 & 5.1 & 0.57 & 28.5 & 0.05 & 3.0 \\
\hline Aspergillus tamarii $\mathrm{M}-68$ & 3.7 & 0.27 & 18.6 & 0.28 & 41.2 \\
\hline Aspergillus candidus $\mathrm{M}-70$ & 0.8 & 0.16 & 15.0 & 0.06 & 8.3 \\
\hline Aspergillus oryzae var. globosus $\mathrm{M}-71$ & 1.5 & 0.08 & 6.0 & 0.02 & 3.8 \\
\hline Aspergillus flavus IFO 5839 & 2.5 & 0.13 & 9.0 & 0.23 & 30.9 \\
\hline Penicillium chrysogenum IFO 4626 & 2.3 & 0.02 & 10.5 & 0.03 & 3.8 \\
\hline Penicillium oxalicum IFO 5750 & 2.8 & 0.04 & 15.8 & 0.03 & 3.8 \\
\hline Neurospora crassa IFO 6068 & 3.5 & 0.03 & 14.3 & 0.02 & 3.8 \\
\hline Endomyces hordei IFO 0104 & 1.2 & 0.00 & 3.2 & 0.00 & 1.2 \\
\hline Endomyces lindneri IFO 0106 & 1.7 & 0.00 & 2.4 & 0.07 & 0.9 \\
\hline Pichia polymorpha IFO 0195 & 1.0 & 0.00 & 1.8 & 0.00 & 0.6 \\
\hline
\end{tabular}
in text.

The reaction was carried out under the standard assay conditions with cell free extract described

* PIN-P; Pyridoxine-P.

10) R. S. Breed, E. G. D. Murray and N.R. Smith, "Bergey's Manual of Determinative Bacteriology", 7th Ed., The Williams and Wilkins Co., 1957.
11) H. Wada and E. E. Snell, J. Biol. Chem., 236, 2089 (1961).

12) S. Omori, Enzymol., 4, 217 (1937).

13) O. H. Lowry, N.J. Rosenbrough, A. L. Forr and R. T. Randall, J. Biol. Chem., 193, 265 (1951). 
ative bacterial strains are studied together with the activities of the other microorganisms which were found to give the considerable activity when these dried cell system was employed." As shown in Table II, it was observed that the cell free extracts of these bacteria, Aspergillus, Penicillium and Neurospora had the ability to form pyridoxineP. The activities in Endomyces and Pichia, however, were weakly observed in the dried cell system but were not detected in cell free extracts. The enzyme activity of bacteria at alkaline $\mathrm{pH}$ range, which appeared to be stronger than at acidic $\mathrm{pH}$ range with the experiment employing the bacterial dried cell system, almost disappeared with the treatment for preparing the enzyme extraction. While the cell free extract of Aspergilli had two or three optimal $\mathrm{pHs}$ for both of the reactions.

Identification of the isolated bacterial strains.

The taxonomic positions of three bacterial strains contained in Table II were identified as follows:

K-1 strain; 1) Morphological: Short rod, 0.4 to 0.6 by 0.8 to 1.8 microns, occurring singly. Motile with flagella. Gram-negative.

2) Cultural:

Bouillon-agar slant: Filiform, translucent growth.

Gelatin stab: Liquefaction.

Potato: Abundant, grayish white, sebaceous growth.

3) Physiological:

Litmus milk: Acid and coagulation.

Litmus reduced.

Indole is produced.

Lactic acid is produced.

Hydrogen sulfide is produced.

Methyl red test positive. Voges-Proskauer test positive.

Acid and gas from glucose, fructose, arabinose, xylose, raffinose, lactose, maltose, glycerol, mannitol, sucrose. Dulcitol, starch, dextrin, inulin are scarcely or not at all fermented.
Citric acid utilized as a sole source of carbon.

Nitrites is produced from nitrates.

Catalase-positive.

Growth requirements: Good growth on ordinary laboratory media.

Optimum growth temperature, between $30^{\circ} \mathrm{C}$ and $37^{\circ} \mathrm{C}$.

Killed at $70^{\circ} \mathrm{C}$.

According to Bergey's Manual, the present strain, K-1, seems to be similar to Escherichia freundii. The type culture of Escherichia freundii S-96 did not showed the appreciable transphosphorylation activity.

The strains, 68303 and 810 , were identified by the same manner to be similar to Pseudomonas pseudomallei and Aerobacter aerogenes, respectively, according to Bergey's Mannual.

Properties of the transphosphorylation.

Several properties of the transphosphorylation, using mainly $p$-NPP and pyridoxine as phosphoryl donor and acceptor substrates, were investigated with the partially purified enzyme preparation from Escherichia freundii $\mathrm{K}-1$. In the following results, the enzyme activity of phosphotransferase was estimated by the formation of pyridoxine- $P$, and that of phosphatase by the liberation of $p$-NP.

Effect of pH. The results of experiments on the effect of the variation of $\mathrm{pH}$ on the activities are presented in Fig. 1. The maximum values for the phosphotransferase activity was observed near $\mathrm{pH}$ 6.0. The phosphatase also showed the same $\mathrm{pH}$ optimum for the activity. The phosphatase in the preparation should be classified to acid phosphatase.

Effect of enzyme concentration. The influence of enzyme concentration on the pyridoxine-P formation was examined. As shown in Fig. 2 , the amount of pyridoxine-P was rapidly decreased with the increase of enzyme concentration, when the increase of the amount of $p$-NP was depressed. The amount of pyridoxine-P formed also diminished with further incubation time with relatively low concentration of enzyme, and then the hydrolysis 


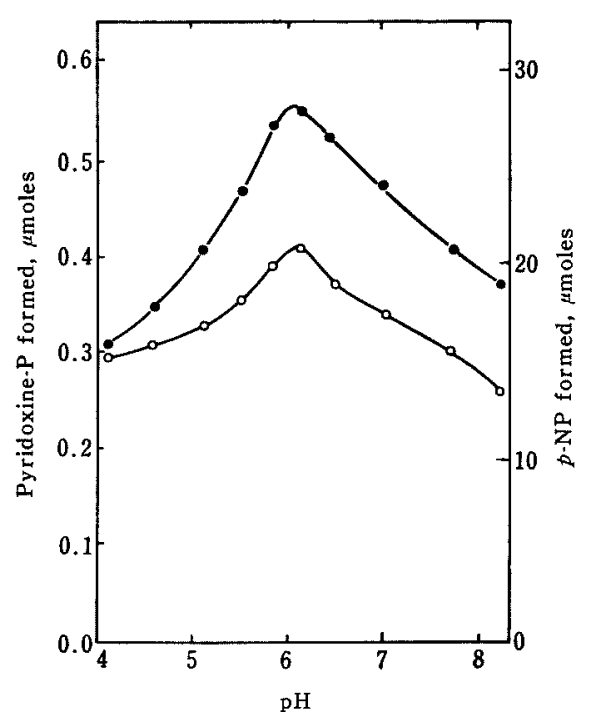

FIG. 1. pH-Activity Curves of Phosphatase and Phosphotransferase Activities.

(๑) Pyridoxine-P formed, (O) $p$-NP formed. The enzyme assay was carried out under the standard conditions with partially purified enzyme preparation ( $1 \mathrm{mg}$ of protein) and Tris-maleate buffer at various $\mathrm{pH}$ values.

of $p$-NPP was rather slow. These might be caused probably because inorganic phosphorus and $p$-NP, which were the effective inhibitors, presented in large amounts in the reaction mixture.

Optimum temperature. The optimum temperature for both the phosphotransferase and phosphatase activities of the enzyme was near $35^{\circ} \mathrm{C}$ (Fig. 3).

Metal ion effect. The effect of various metal ions listed in Table III were examined at the final concentration of $10^{-3} \mathrm{M}$. None of metal ion accelerated either of the enzyme activities. $\mathrm{Zn}^{2+}, \mathrm{Cu}^{2+}, \mathrm{Hg}^{2+}$ and $\mathrm{MoO}_{4}{ }^{2-}$ inhibited the reaction. The inhibitory effect of $\mathrm{Co}^{2+}$ on the phosphotransferase activity might be confirmed to be the inhibition against the activity of the enzyme used for the assay, pyridoxine-P oxidase. The stimulating effect of several metal ions on nucleoside phospho-

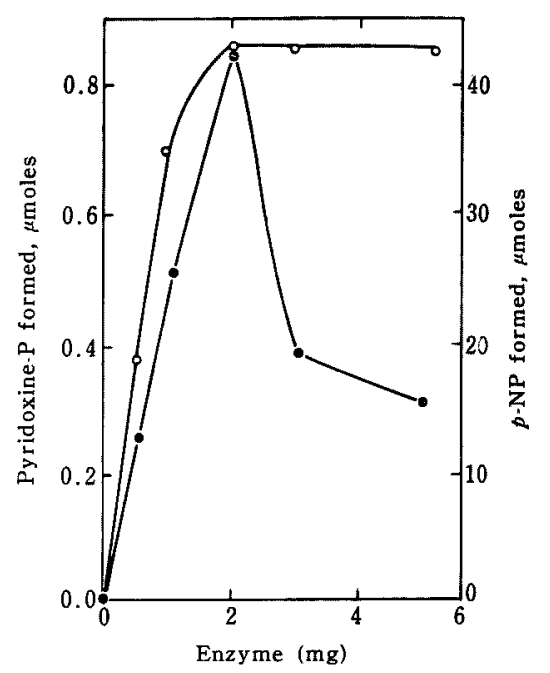

FIG. 2. Effect of Enzyme Concentration on Phosphatase and Phosphotransferase Activities.

(C) Pyridoxine-P formed, (O) $p$-NP formed. The enzyme assay was carried out under the standard conditions with partially purified enzyme preparation.

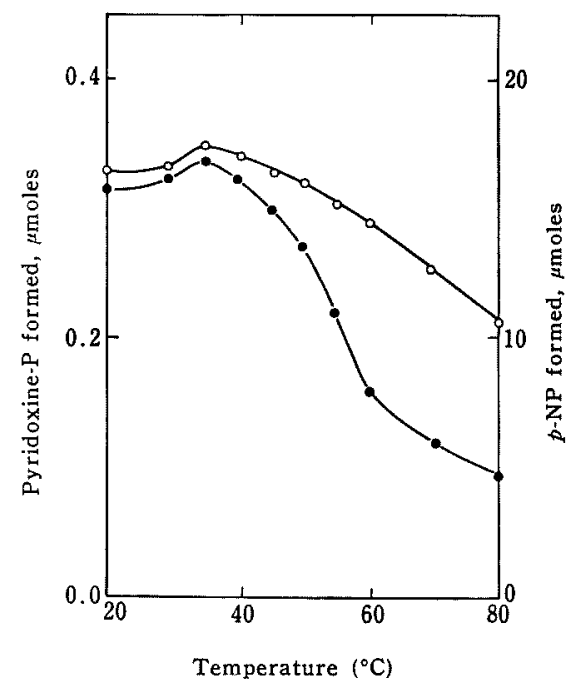

FIG. 3. Effect of Temperature on Phosphatase and Phosphotransferase Activities.

(O) Pyridoxine-P formed, (O) $p$-NP formed. The enzyme assay was carried out under the standard conditions with partially purified enzyme preparation ( $0.8 \mathrm{mg}$ of protein) except for the reaction temperature. 
TABLE III. EFFect of Metal Ion on Phosphatase and PhosphotransFERASE ACTIVITIES

$\begin{array}{lcc}\begin{array}{c}\text { Metal ion } \\ \left(10^{-3} \mathrm{M}\right)\end{array} & \begin{array}{c}\text { Pyridoxine-P } \\ \text { formed } \\ \text { (Relative }\end{array} & \begin{array}{c}p \text {-NP } \\ \text { formed }\end{array} \\ \mathrm{None} & (100) & (100) \\ \mathrm{Mg}^{2+} & 100 & 102 \\ \mathrm{Mn}^{2+} & 100 & 98 \\ \mathrm{Fe}^{2+} & 85 & 90 \\ \mathrm{Zn}^{2+} & 74 & 83 \\ \mathrm{Ni}^{2+} & 89 & 90 \\ \mathrm{Cu}^{2+} & 85 & 87 \\ \mathrm{Co}^{2+} & 56 & 98 \\ \mathrm{Ca}^{2+} & 96 & 90 \\ \mathrm{Hg}^{2+} & 63 & 76 \\ \mathrm{Cr}^{3+} & 85 & 94 \\ \mathrm{Li}^{+} & 96 & 94 \\ \mathrm{MoO}_{4}^{2-} & 81 & 81 \\ (\mathrm{EDTA}) & (96) & (96)\end{array}$

The enzyme assay was carried out under the standard conditions with partially purified enzyme preparation $(0.3 \mathrm{mg}$ of protein), adding $3 \mu$ moles of each metal ions.

transferase has been demonstrated in detail. ${ }^{141}$ The inhibitory or accelerating effect of metal ions on phosphatase has also been reported. ${ }^{15,16)}$ As mentioned above, the metal ions did not affect the enzyme activities in the present preparation.

Inhibitor effect. A number of compounds were tested as inhibitors of the phosphotransferase and phosphatase activities at different concentrations indicated in Table IV. Sodium fluoride and inorganic phosphorus, which were the typical competitive inhibitors of acid phosphatase, inhibited both of these activities over at $10^{-3}$ or $10^{-2} \mathrm{M}$. $\mathrm{Hg}^{2+}$ was also inhibitory with lower concentration. (+) Tartarate and oxalate, which have been reported to inhibit acid phosphatase on the hydrolysis of $p$ NPP ${ }^{171}$ did not inhibit the activity of this

14) K. Mitsugi, Agr. Biol. Chem., 28, 669 (1964). 15) D. J.D. Nicholas and K. Commissiong, $J$. Gen. Microbiol., 17, 699 (1957).

16) H. Z. Newmask and B.S. Wengner, Arch. Biochem. Biophys., 89, 110 (1960).

17) V.N. Nigam, H.N. Davidson and W. H. Fishman, J. Biol. Chem., 234, 1550 (1959).

Table IV. EFfect of INHIbItor on Phosphatase and Phosphotransferase activities

Inhibitor

None

$\mathrm{NaF} 10^{-4} \mathrm{M}$

$10^{-3} \mathrm{M}$

$10^{-2} \mathrm{M}$

$\mathrm{KCN}$

$\mathrm{NaAsO}$

$\mathrm{Na}_{2} \mathrm{HAsO}_{4}$

Pyrophosphate

$\mathrm{KH}_{2} \mathrm{PO}_{4} 10^{-3} \mathrm{M}$ $10^{-2} \mathbf{M}$

(+) Tartarate

Oxalate

PCMB

$o$-Phenanthroline

$\alpha, \alpha^{\prime}$-Dipyridyl

EDTA

$\mathrm{HgCl}_{2} \quad 10^{-4} \mathrm{M}$

$$
10^{-3} \mathrm{M}
$$$$
10^{-2} \mathrm{M}
$$

Deoxypyridoxine

4-Pyridoxic acid

$\begin{array}{cc}\begin{array}{c}\text { Pyridoxine-P } \\ \text { formed } \\ (\text { Relative activity) }\end{array} & \begin{array}{c}p \text {-NP } \\ \text { formed }\end{array} \\ (100) & (100) \\ 100 & 100 \\ 67 & 73 \\ 16 & 45 \\ 95 & 100 \\ 95 & 100 \\ 100 & 100 \\ 95 & 106 \\ 100 & 96 \\ 84 & 86 \\ 100 & 100 \\ 98 & 100 \\ 100 & 103 \\ 100 & 103 \\ 100 & 100 \\ 96 & 97 \\ 82 & 94 \\ 64 & 83 \\ 23 & 60 \\ 100 & 103 \\ 100 & 103\end{array}$

The enzyme assay was carried out under the standard conditions with partially purified enzyme preparation $(0.3 \mathrm{mg}$ of protein), adding inhibitor, $3 \mu$ moles except for PCMB (0.3 $\mu$ moles), and $\mathrm{NaF}$, $\mathrm{KH}_{2} \mathrm{PO}_{4}$ and $\mathrm{HgCl}_{2}$ (indicated) in a total volume of $3 \mathrm{ml}$.

\section{enzyme preparation.}

Substrate specificity. Various phosphates were tested as phosphoryl donor substrate for the pyridoxine-P formation (Table V). It was shown that the enzyme was capable of transferring the phosphoryl moiety of a variety of the compounds to pyridoxine, and that $p$-NPP and fructose 1,6-diphosphate were the most excellent donor substrate.

Table VI shows the acceptor specificity of the free form of vitamin $B_{6}$. Pyridoxine was phosphorylated in rather high rate. The phosphorylation of pyridoxal was lower with the transphosphorylation under the condition employed. It has been shown that all of pyridoxal phosphokinase phosphorylate pyri- 
TABLE V. PHOSPHORYL DONOR SPECIFICITY

$\begin{array}{lc}\text { Donor substrate } & \begin{array}{c}\text { Pyridioxine-P } \\ \text { formed } \\ (\mu \text { moles })\end{array} \\ p \text {-NPP } & 0.36 \\ \text { Phenyl-P } & 0.18 \\ \text { Phenolphthalein-2-P } & 0.08 \\ \text { Fructose-1, 6-P } & 0.47 \\ \alpha \text {-Glycero-P } & 0.12 \\ 5^{\prime} \text {-Adenylic acid } & 0.03 \\ \text { 5'-Cytidylic acid } & 0.03 \\ \text { 5'-Guanylic acid } & 0.05 \\ 5^{\prime} \text {-Inosinic acid } & 0.07 \\ \text { 5'-Uridyric acid } & 0.08 \\ \text { Acetyl-P } & 0.25 \\ \text { Creatine-P } & 0.00 \\ \text { ATP } & 0.02 \\ \text { Pyrophosphate } & 0.00 \\ \text { None } & 0.00\end{array}$

The enzyme assay was carried out under the standard conditions with partially purified enzyme preparation $(0.45 \mathrm{mg}$ of protein) without $p$-NPP. The phosphoryl donor substrate added was $50 \mu$ moles.

TABLE VI. Phophoryl ACCePtor SPECIFICITY OF VITAMIN $B_{6}$

Acceptor substrate

$\begin{array}{cc}\begin{array}{c}\text { Vitamin } \mathrm{B}_{*} \cdot \mathrm{P} \\ \text { formed } \\ \mu \text { moles }\end{array} & p \text {-NP formed } \\ \mu \text { moles } \\ 0.46\left(0.41^{*}\right) & 16.8 \\ 0.12\left(0.03^{*}\right) & 16.5 \\ -(0.01 *) & 16.5\end{array}$

$\begin{array}{lcc}\text { Pyridoxine } & 0.46\left(0.41^{*}\right) & 16.8 \\ \text { Pyridoxamine } & 0.12\left(0.03^{*}\right) & 16.5 \\ \text { Pyridoxal } & -(0.01 *) & 16.5\end{array}$

The enzyme assay was carried out under the standard conditions with partially purified enzyme preparation $(0.45 \mathrm{mg}$ of protein) without pyridoxine. Each vitamin $B_{6}$ added were $10 \mu$ moles.

* The values were obtained with the assay of apotryptophanase method.

doxal, pyridoxamine and that pyridoxal is generally the preferred substrate for the kinase. $^{21}$

\section{DISCUSSION}

As for the enzymatical phosphorylation, phosphokinase system, capable of transferring the phosphoryl moiety of ATP to acceptor, is known to be the most common system.

On the phosphorylation of vitamin $\mathrm{B}_{6}$ it has been demonstrated to be catalyzed by the action of pyridoxal phosphokinase in the presence of ATP as phosphoryl donor. ${ }^{181}$ It was also found that a few other nucleoside triphosphate was also available as phosphoryl donor substrate in the enzyme system, though ATP was the preferred substrate. ${ }^{2}$

On the other hand, the transphosphorylation between a variety of organic phosphates not involved ATP and other phosphoryl acceptor has been investigated with several enzyme systems. These contain the transphosphorylation activities of phosphatases and that of phosphotransferases. The mechanisms of the reaction, however, has not still been elucidated satisfactory especially the identity of both the enzymes. Since the works of Axelrod ${ }^{51}$ and Appleyard $^{191}$ with acid phosphatase, many works on the phosphotransferase activity of certain phosphatase preparations have shown that phosphoryl transfer occurs in the absence of high-energy donors to acceptors like simple alcohols and sugars. While, Brawerman and Chargaff $^{6 !}$ were the first to discover a group of enzymes which they designated as "nucleoside phosphotransferase" which were capable of transferring esterified phosphoric acid to nucleosides. The enzyme has been also demonstrated in the various bacteria. ${ }^{201} \mathrm{~A}$ few phosphotransferase, which was considered to be different from phosphatase, such as glucose1-phosphate phosphotransferase has been also discovered. ${ }^{211}$

The phosphorylation of pyridoxal by enzymes other than pyridoxal kinase was attempted by Axelrod and resulted in no success using plant phosphatase." Recently, Kumar and Vaidyanathan have been shown that the preparation of the enzyme hydrolyzing flavinmononucleotide from green gram extracts possessed the phosphotransferase ac-

18) J. Hurwitz, J. Biol. Chem., 205, 935 (1953).

19) J. Appleyard, Biochem. J., 42, 596 (1948).

20) K. Mitsugi, K. Komagata, M. Takahashi, H. Iizuka and H. Katagiri, Agr. Biol. Chem., 28, 586 (1964).

21) H. Katagiri, H. Yamada and K. Imai, $J$. Biochem., 46, 1119 (1959). 
tivity. ${ }^{22)}$ They have been briefly reported that the enzyme could transfer the phosphoryl group cleaved from flavinmononucleotide to pyridoxal and pyridoxamine result in the formation of their corresponding phosphate esters.

The phosphorylation of vitamin $\mathbf{B}_{6}$ presented here provide the first clear-cut evidences for the formation of phosphorylated coenzymes by a phosphotransferase reaction. The enzyme preparation used in this experiments also appeared to have a strong acid phosphatase activity. Both the enzyme activities were compared using mainly $p$-NPP and pyridoxine as phosphoryl donor and acceptor substrates in this paper.

The optimum $\mathrm{pH}$ for the phosphotransferase activity was observed to be 6.0 the same as that of phosphatase. The optimum temperature for the transphosphorylation was found to be $35^{\circ} \mathrm{C}$, and the enzyme was not inactivated by the heat treatment for $10 \mathrm{~min}$ below $60^{\circ} \mathrm{C}$. These effect of temperature on the transphosphorylation were also the same with that of the hydrolyzation. The inhibition of inorganic phosphorus and sodium fluoride on phosphatase activity has been investigated by several groups of workers. The phosphatase described here was moderately inhibited by the addition of these compounds to the reaction mixture, accompanying with the same extent inhibition on the phosphotransferase activity. The behaviour of the phosphotransferase to the action of metal ions and other inhibitors was also identical with that of phosphatase. All the available data thus made to suggest that the phosphoryl group

22) S. A. Kumar and G. S. Vaidyanathan, Biochim. Biophys. Acta, 73, 98 (1963). transfer from $p$-NPP to pyridoxine might be an intrinsic and inherent function of acid phosphatase. The crystallization of the phosphatase was also contributed to the conclusion. ${ }^{23 !}$

Experiments on phosphoryl donor specificity for the enzyme system indicated that the phosphatase was nonspecific and the phosphotransferase reaction might occur under the wide variety of conditions in microoganisms. On phosphoryl acceptor specificity of vitamin $\mathrm{B}_{6}$, pyridoxine was the most excellent substrate followed by pyridoxamine. Pyridoxal phosphokinases from various enzyme sources could phosphorylate the three forms of vitamin $\mathbf{B}_{6}$, though individual kinases differ greatly in their affinities for these compounds. ${ }^{21}$ Pyridoxal-P is known as active coenzyme form of vitamin $B_{6}$ for various metabolism. In spite of these facts and the relative inactivity of pyridoxal for the transphosphorylation described here, the reaction may give the physiological significance because a enzyme, pyridoxine-P oxidase, which is capable of conversion of pyridoxine-P and pyridoxamine- $P$ to pyridoxal-P, exists widely in various aerobic bacteria $^{241}$ and also in the strains used here. ${ }^{251}$

Acknowledgement. The authors wish to thank Dr. H. Yamada, the Research Institute for Food Science, Kyoto University, for valuable discussions. Thanks are given to $\mathrm{Mr}$. S. Kawata for his assistance on screening of bacteria.

23) Y. Tani, T. Tochikura, H. Yamada and K. Ogata, Biochem. Biophys. Res. Commun., 28, 769 (1967)

24) S. Yamamoto, T. Tochikura and K. Ogata, Agr. Biol. Chem., 29, 200 (1965).

25) K. Ogata et al., Unpublished observation. 